\section{BADN WELCOME} ANGIE'S

\section{APPOINTMENT TO GDC}

In July the British Association of Dental Nurses (BADN) welcomed the appointment of Angie Heilmann to the General Dental Council (GDC).

Angie Heilmann (formerly McBain) qualified as a dental nurse in 1989, went on to achieve the NEBDN qualification in Dental Sedation Nursing (with Distinction), for which she was awarded the Roche Prize in 2000, and worked in clinical practice until 2007 before focusing solely on dental nurse education.

Angie has held a number of educational and tutoring positions, most recently as the Dental Workforce Development Regional Advisor for Heath Education England (East) until 2020, and is currently the Director of Dental Nurse Education at Cambridge Dental Nurse Academy, the dental nurse arm of Antwerp Dental Academy. Previously, she was part of the team that introduced Foundation Degrees in Dental Nursing at the University of Bedfordshire.

Angie is not only a Past President of BADN, but also a former Chair, Regional Coordinator and Chair of the National Teaching Group, and was awarded the BADN Outstanding Contribution to

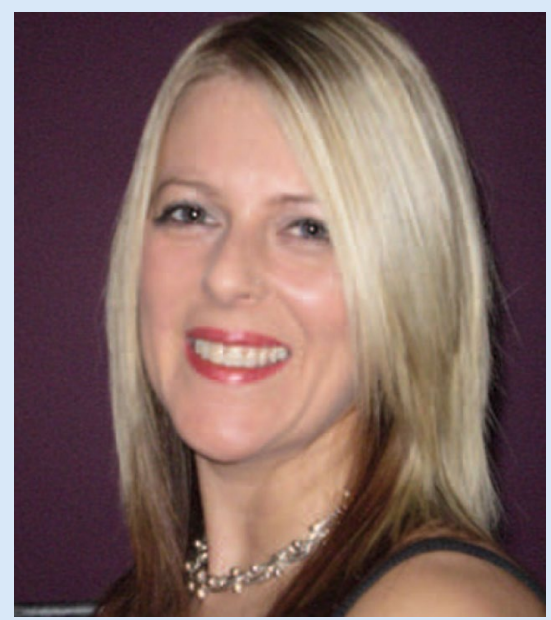

Dental Nursing Award in 2011.

Angie was also Chair of the Local Dental Education Committee at Luton and Dunstable Hospital, and is the only dental nurse to have sat on the Council of the Society for the Advancement of Anaesthesia in Dentistry (SAAD). She holds a Master's degree in Medical Education from the University of Bedfordshire and was awarded an MBE for Services to Dental Nursing in 2012.

BADN President Jacqui Elsden said: 'We are extremely pleased that former BADN President Angie Heilmann has been appointed a registrant council member of the GDC. I have no doubt that Angie will bring to this role a wealth of expertise to ensure a fair and proportionate experience for dental professionals, leading to improved confidence in our profession'.
BDA training online for the whole dental team

Adult and child safeguarding Interactive workshop, limited to a small group

Friday 1 October 2021

4 hours of CPD

Book online: https://www.bda.org/events/ Pages/Adult-and-child-safeguardingFriday-1-October-2021-ONLINE.aspx

Managing challenging patients and diffusing difficult situations Interactive workshop, limited to a small group

Friday 12 November 2021

3.5 hours of $\mathrm{CPD}$

Book online: https://www.bda.org/events/ Pages/Managing-challenging-patients-

Friday-12-November-2021-ONLINE.aspx

Reception and telephone skills Interactive workshop, limited to a small group

Friday 10 December 2021

3.5 hours of $\mathrm{CPD}$

Book online: https://www.bda.org/events/ Pages/Reception-and-telephone-skillsFriday-10-December-ONLINE.aspx

\title{
DR DEBBIE REED RECEIVES INAUGURAL JANET GOODWIN AWARD
}

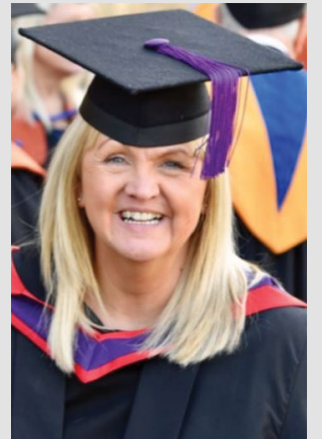

The British

Association of Dental Nurses (BADN) is delighted that long standing member Dr Debbie

Reed is the first recipient of the FGDP(UK)'s Janet Goodwin Award,

awarded to the dental care professional (DCP) who has advanced the role of and empowered DCPs in order to educate and improve oral healthcare.

The Award, which honours the late dental nurse Janet Goodwin, is focused on the all-round performance and skills required to become a passionate and committed advocate for DCPs, reflecting Janet's legacy. The Award highlights the qualities of leading by example, a commitment to lifelong learning that goes beyond statutory requirement, and a wider commitment to the dental profession.

Dr Debbie Reed is Head of the Department for Digital and Lifelong Learning at the University of Kent where she established, and remains the course director of, the Master's degree in Advanced and Specialist Healthcare. Debbie has also been leading the development of degree and higher apprenticeships for the University, building links with employers across the UK and various industries.

Debbie has been a BADN member for more than 20 years, and is a former BADN Executive Committee Chair. In 2020 she was awarded the BADN Outstanding Contribution to Professional Practice Award.

Dr Reed said: 'I am reassured that my work as an educator and my research has practical application and has provided transformational opportunities to those employed across the whole of the dental sector. I had the honour to know Janet Goodwin as colleague; she also contributed to my research, which makes receiving a prize in her name so meaningful and such a poignant privilege'. 